\title{
SQUARE TALKS®: A MOBILE APP TO SUPPORT EFL LEARNERS' VOCABULARY DEVELOPMENT
}

\author{
${ }^{\# 1}$ Ima Normalia Kusmayanti, ${ }^{* 2}$ Retno Hendryanti
}

${ }^{\# 1}$ English Lecturer, School of Industrial Engineering, Universitas Telkom, Indonesia

${ }^{* 2}$ English Lecturer, School of Electrical Engineering, Universitas Telkom, Indonesia

Corresponding Author Email: kusmayanti@telkomuniversity.ac.id

\begin{abstract}
A B S T R A C T S
In recent years, mobile-based game language learning has proliferated due to its promising prospects and positive impacts in improving teaching and learning outcomes in English vocabulary development. With this phenomenon, Square Talks ${ }^{\circledR}$ was developed specifically to aid EFL beginner learners with their English vocabulary. This study aims to examine the effectiveness of the game app in developing the learners' English vocabulary development. This study employed a quantitative approach focusing on 34 EFL beginner learners. The focus has been on how effective the game app was statistically and overall experience of using the game app. Data were collected through vocabulary tests and a survey. The test results showed that Square Talks® has improved the subjects' English vocabulary development with the t-value of the test results is -19.93 indicating a significant effect in increasing the subjects' English vocabulary development. The survey result revealed positive acceptance toward playing Square Talks ${ }^{\circledR}$ in terms of effectiveness (4.49), usability (4.34), and satisfaction (4.52). Therefore, Square Talks ${ }^{\circledR}$ can be considered to be an alternative learning tool to facilitate EFL beginner learners' vocabulary development.
\end{abstract}

\begin{tabular}{l}
\hline \multicolumn{1}{c}{ A R T I C L E I N F O } \\
\hline Article History: \\
Received: November, 2021
\end{tabular}

Revised: November, 2021

Published: December, 2021

How to cite: Kusmayanti, I., \& Hendryanti, R. (2021). Square Talks®: A Mobile App to Support EFL Learners' Vocabulary Development. Jo-ELT (Journal of English Language Teaching) Fakultas Pendidikan Bahasa \& Seni Prodi Pendidikan Bahasa Inggris IKIP, 8(2), 139-151. doi:https://doi.org/10.33394/joelt.v8i2.4393

\section{INTRODUCTION}

The ongoing COVID-19 outbreak has had a profound impact on various aspects of life, including the learning process in schools. This current situation has shifted teachers and students from doing activities in face-to-face language classes to studying and working online. In the case of EFL classes, teachers have started utilizing various digital learning spaces such as the school's learning management system and many free web-based applications. Any online applications capable of retaining EFL students' engagement to the learning process is needed. In response to the call on online learning strategies, this study is aimed at providing alternative vocabulary learning through a mobile game-based application. Research showed that learning vocabulary in a foreign language using mobile applications has positive impacts on learners' learning performance (Kohnke, Zhang, \& Zou, 2019; Li, 2021; Rezaei, Neo, \& Pesaranghader, 2013) and has successfully generated positive perceptions as well as increased learning motivation (Fageeh, 2013; Gamlo, 2019; Goz Ozcan, 2017; Klimova \& Polakova, 2020). 
In the context of learning EFL in Indonesia, it is evident that vocabulary is considered necessary for language proficiency. Nevertheless, acquiring English vocabulary development at a reasonable level for many Indonesian EFL beginner learners is difficult due to complex differences between Indonesian and English words including pronunciation, spelling, word form, word meaning, and word use (Rohmatillah, 2017; Salam \& Nurnisa, 2021). Carcamo at.al. (2016) highlighted that the prevailing problems in EFL vocabulary were mainly caused by inadequate and outdated practices such as memorizing lists of decontextualized words and the excessive use of translation when teaching vocabulary. Further, previous research reported that foreign language learners, especially at beginner level, struggle with learning, memorizing, and using English vocabulary (Cahyono \& Widiati, 2008; Nation, 2008; Schmitt, 2008). Thus, it is fundamental to provide an effective learning tool to facilitate EFL beginners' vocabulary acquisition.

Vocabulary is the core of language proficiency and provides the basis for improving listening, reading, speaking, and writing skills (Richards \& Schmidt, 2002). Cameron (2001) posits that when someone learns EFL vocabulary, word learning includes the root words that may have different parts of speech with the vocabulary being learned. For example, the noun "development" has the root word of "develop" which has a part of speech and a different meaning. Harmer (2002) explains that EFL learners typically face three challenges: (1) making connections between words correctly, (2) understanding the form and meaning of words, and (3) distinguishing the meaning of words that are closely related to a word.

Literature on vocabulary development shows that there are two major approaches to effective foreign language vocabulary acquisition: (1) long-term retention, and (2) effective retrieval. The first approach includes spaced repetition (Nation, 2008; Schmitt, 2008) and multimodal presentation (Chun \& Plass, 1996; Mayer \& Moreno, 2003). Spaced repetition is a series of presentations and exercises of word knowledge to maximize learners' exposures to words (Schmitt, 2008). Woźniak and Gorzelańczyk (1994) asserted that the repetition intervals of knowledge presentation should be within the time learners still retain the knowledge. Favorable outcomes on the implementation of spaced repetition in EFL vocabulary learning were proven by Chukharev-Hudilainen \& Klepikova (2016) who investigated how spaced repetition can lead to a nearly threefold improvement of vocabulary learning obtained by EFL learners. Moreover, Lotfolahi \& Salehi (2017) revealed that spaced repetition practices were better in long-term retention than massed repetition practices. Naderi (2017) highlighted that spaced repetition worked the best when recalling single words, but not collocations (a series of words that co-occur to make up a meaning). Nation (2008) emphasized that the number of repetitions should range from five to seven in accordance with the levels and preferences of individual learners. This is because the purposes of the repeated presentations and exercises are to intensify learners' understanding and extend their knowledge retention.

The second approach is multimodal presentation. In this case, word knowledge is presented in multiple media. This approach is closely related to the cognitive theory of multimedia learning in which word knowledge develops through visual and auditory channels (Mayer \& Moreno, 2003). Furthermore, Chun \& Plass (1996) noted that when learners see word knowledge in two channels, they receive stimulations and use both channels to establish connections between what they receive and their storage in memory. Toroghi \& Anaraki (2015) examined that compared to the single-mode instruction, the multimodal instruction was more beneficial to EFL learners' vocabulary learning. Moreover, Carcamo, et.al. (2016) demonstrated that the use of multimodality in the classroom context significantly benefits the EFL learners' in their process of learning new vocabulary. There was an improvement in students' vocabulary acquisition after the multimodal sessions. Hence, the concept of 
multimodal principle facilitates learners to have longer memory retention and accelerate their knowledge retrieval.

In our study, target words are situated in four different exercises emphasizing on pronunciation, spelling, word meaning, and word use. The target words are also presented in multimodal stimulations with the combination of audio-text and audio-picture. In other words, the vocabulary learning experiences were designed based on the notion of spaced repetition and multimodal presentation approaches, all of which are aimed at facilitating constructive learning to enhance learners' word acquisition for longer retention and effective retrieval (Zarei \& Khazaie, 2011). The target words are introduced to EFL learners in the form of a mobile game-based application.

Today, a wide range of language learning games are available on mobile applications. Digital games for educational purposes have enabled multitude of engagements in language learning (Goz \& Ozcan, 2017), especially in vocabulary acquisition (Liu, 2016). Digital games have facilitated EFL learners to retain newly acquired vocabulary through ubiquitous learning (Yen, Chen \& Huang, 2019). Yip \& Kwan (2006) reported that EFL learners who are digital natives considered it boring to learn vocabulary from a word list. The negative perception toward learning vocabulary from a word list might affect the success of the learners in gaining vocabulary knowledge. There is a call for turning the traditional drill and practice EFL vocabulary learning process into an enjoyable experience with the help of digital games to provide a learning space that digital natives are familiar with.

The practicality and popularity of mobile devices have contributed positively to the teaching and learning process (Pavlik, 2005). Stockwell \& Hubbard (2013) highlighted that the existence of a smartphone with hardware and software is able to present a learning experience like a computer. In recent years, mobile learning has been considered a promising approach for successful vocabulary knowledge acquisition and retention (Basal, at.al., 2016; Deris \& Shukor, 2019; Fageeh, 2013; Kohnke, Zang, \& Zou, 2019; Ludwig, 2018; Rezaei, Neo, \& Pesaranghader, 2013; Wu, 2018; Yen, Chen \& Huang, 2019) based on its potential to engage learners to learn, practice, and enhance their language proficiency. Zou \& Li (2015) highlighted that user-friendly mobile game apps made students feel enthusiastic and show eagerness in learning. Pareja-Lora et.al. (2013) argued that with varied features and potentials of mobile apps, there is a possibility that they only deliver fragmented learning practices. Moreover, by providing flexibility, practicality, and personalization, mobile-based learning actually brings more challenges than traditional teaching and learning (Kukulska-Hulme \& Traxler, 2005). However, these challenges are worth the results of successful learning experiences.

Indeed, digital games such as mobile game applications have the highest potential for bringing interesting, motivating, and stimulating learning opportunities both inside and outside the classroom due to their flexibility, practicality, and personalization (Akhriana, 2019; Chen, Liu, \& Huang, 2019; Gamlo, 2019; Kohnke, Zhang, \& Zou, 2019; Li, et.al., 2019; Li, 2021; Yip \& Kwan, 2006). In response to successful mobile-learning experiences, researchers (Gamlo, 2019; Li, 2021; Wu, 2018; Yen, Chen \& Huang, 2019) have incorporated vocabulary learning contents not only into a digital platform, but also in the playful activity that includes game rules, social interactions, challenges, and instant feedback that brings us to the term mobile-based game learning (MBGL). The term MBGL expresses the concept of educational entertainment or entertainment-education wrapped in educational games or serious games allowing learners to learn subject matter with entertainment. Researchers who examined the implementation of MBGL in EFL vocabulary learning discovered that learners manifested positive attitudes (Gamlo, 2019; Li, 2021; Wu, 2018; Yen, Chen \& Huang, 2019), eagerness in learning (Li, 2021; Wu, 2018; Yen, Chen \& Huang, 2019), high self-confidence in learning ( $\mathrm{Li}, 2021$ ), and significant improvement in their 
vocabulary acquisition (Li, 2021; Yen, Chen \& Huang, 2019). Li, et.al. (2019) conducted an empirical study on flow theory and concluded that game-based vocabulary learning facilitated EFL learners to show affective perceptions with high intrinsic motivation, the balance of skill and challenge, playability, enjoyment, satisfaction, and positive attitude toward learning. While the findings of these studies contribute positively to the pedagogical benefits of game-based vocabulary learning, there are limitations for further consideration. Further studies should focus on the improvement of learners' vocabulary accuracy, specifically addressing EFL beginners.

With this background, Square Talks ${ }^{\circledR}$ was developed to aid EFL beginners with their English vocabulary development. Square Talks® is designed for Indonesian EFL learners learning English vocabulary in rich linguistic and thematic contexts. The theme of the game is "Nusantara" presenting prolific information on Indonesian cultures from Sabang until Merauke. The game flow is designed based on the integration of content and language integrated learning (CLIL), second language (L2) learning, and gaming principles. This study reported a preliminary study to examine the effects of the game app to enhance learners' English vocabulary knowledge under two guiding questions: (1) How effective has the use of the game app been to enhance learners' English vocabulary development?; and (2) How do the learners perceive the experience of learning English vocabulary using the game app?

\section{RESEARCH METHOD}

\section{Research Design}

This study aimed to examine the effectiveness of Square Talks® in increasing EFL beginner learners' vocabulary size. In addition, this study surveyed the learners' perceptions and feedback on the overall experience learning English vocabulary using the game app.

One design pre-test and post-test was implemented to evaluate the effectiveness of Square Talks ${ }^{\circledR}$ in improving students' English vocabulary learning performance. The null hypothesis $\left(\mathrm{H}_{\mathrm{o}}\right)$ was there is no significant difference between the means of the vocabulary tests before and after the experimental treatment. The alternative hypothesis $\left(\mathrm{H}_{1}\right)$ was there was a significant difference between the means of the vocabulary tests before and after the experimental treatment.

Due to the study from home (SFH) policy and restriction of public meetings in the ongoing COVID-19 pandemic, communications and coordination between students and researchers were done using online modes. All students were invited in a WhatsApp group and monitored weekly. Before students were exposed to the experimental treatment, they took a vocabulary pre-test. Then, they were assigned to learn the target vocabulary from the game app for at least four hours per week. They could decide their own time arrangement to use the game app for vocabulary learning. To evaluate the effectiveness of the game app in facilitating vocabulary learning, a vocabulary post-test was immediately conducted at the end of the four-week experimental period. Moreover, a questionnaire was distributed to the students to elicit their acceptance toward the use of Square Talks® as a vocabulary learning tool.

\section{Population and Sample}

In this study, the target research population was Indonesian beginner EFL learners in 7th grade of a public junior high school in Bandung, West Java. 34 students were selected randomly as the research samples meeting the general requirement of the large enough sample condition in which the number of the sample (n) $\geq 30$ for quantitative research (Arikunto, 2019). They agreed to fully participate in the study from February-April 2021. All students involved in this study had access to Android smartphones that meet the requirement of hardware and software and internet connections and were familiar with Android mobile 
game applications. It was very important for the samples to have an Android mobile phone with $720 \times 1280$ pixels, $1 \mathrm{~GB}$ RAM, 300MB storage, Dual Core $2.0 \mathrm{GHz}$ processor, excellent audio quality, and Google Play Games service installed on their phones. The minimum requirement of hardware and software and internet connection is necessary to reduce any technical glitches that may occur during the experimental treatment period.

\section{Instruments}

There were two instruments employed in the data collection of this study namely: (1) vocabulary tests; and (2) a questionnaire survey. Vocabulary tests were developed to evaluate the effectiveness of Square Talks ${ }^{\circledR}$ in improving students' English vocabulary learning performance. The multiple-choice questions in the vocabulary tests adopted the structure and form of vocabulary size test developed by Nation \& Beglar (2007) to measure the students' ability to identify the correct Indonesian words equivalent to the English word. The test was administered twice, once before the students played the game app and the other one after the students played the game app.

To ensure the content validity of the vocabulary tests, three language experts evaluated the content and linguistic aspects of the tests, including the instruction, questions, and options for answers to ensure the test readability and level of difficulty. All aspects are confirmed to be grammatically correct, not ambiguous, and unbiased. All questions had also been confirmed to represent various cultures in Indonesia, avoiding any exclusivity of certain cultures.

Further, the Pearson's Moment Correlation with validity coefficient of $\geq 0.30$ and the significance level $\alpha=0.05$ was employed to assess the construct validity of the vocabulary test. Based on the results, the lowest validity coefficient of the test item was .340 and the highest was .813 indicating that the overall vocabulary tests demonstrated construct validity. Moreover, the result of the reliability confirmed by Cronbach Alpha was .957 which was satisfactory with Cronbach Alpha exceeding 0.7.

The second research instrument was a questionnaire which was distributed to collect the students' perspectives and feedback toward using Square Talks ${ }^{\circledR}$ for their English vocabulary learning. The questionnaire consisted of three sections. The first section was intended to gather information related to the students' duration of playing Square Talks®. The second section consists of questions on user experience adapted from Schrepp, Hinderks, \& Thomaschewski's questionnaire (2014) focusing on three dimensions: effectiveness, usability, and satisfaction. Each dimension consists of five questions with a five-point Likert scale. The last section of the questionnaire includes two open-ended questions intended to collect data on problems encountered when playing the game app. The questions in the questionnaire were presented in Indonesian to avoid misunderstanding on the students' side. The questionnaire was distributed to the students on the last day of the experimental treatment. This study employed Cronbach's Alpha with coefficient $>0.7$ to confirm the reliability of the questionnaire in the Indonesian language in which the result of the Cronbach's Alpha was .981 indicating that the overall questionnaire has satisfactory reliability.

\section{Data Analysis}

The first stage of the analysis was to measure the difference between pre-test and posttest using the paired sample t-test to answer the first research question. Prior upon using the paired sample t-test, four conditions must be met: (1) the dependent variable must be continuous; (2) the observations are independent of one another; (3) the dependent variable is normally distributed; and (4) the dependent variable is homogeneous. To meet the third and fourth criteria, the Shapiro Wilk test and the Levene test were employed to determine the normality and homogeneity of the data. The Shapiro Wilk test was employed to determine the 
distribution of the data with the level of significance $(\alpha)$ of 0.05 in which the significance value ( $p$-value) $>0.05$ means that the data are normally distributed. Moreover, the Levene test was employed to determine the homogeneity of variance with the $\alpha=0.05$ in which the $p$ value is greater than 0.05 which means that the data are homogenous. Referring to the t-table after the four conditions were fulfilled, if the result of t-test is higher than t-table at the level of significance $(\alpha)$ of 0.05 as the convention to reject the null hypothesis (Arikunto, 2019), the null hypothesis can be rejected. On the contrary, if the result of t-test is lower than t-table, the null hypothesis cannot be rejected. The inferential statistical analysis was conducted using SPSS version 25.

The second stage of the analysis was focused on the questionnaire data. Data from the first and second sections of the questionnaire were filtered, cross-tabulated, and summarized. Results from open-ended questions of the third section were coded and categorized. The analysis of the questionnaire data was conducted using descriptive method.

\section{RESEARCH FINDINGS AND DISCUSSION Research Findings}

\section{Vocabulary Learning Performance}

Thirty four students were selected to take part in the experiment. Before using the intervention media, all students took a vocabulary pre-test. Then, they were assigned to learn the target vocabulary from the game app. Prior to the intervention period, all students confirmed that they successfully installed Square Talks ${ }^{\circledR}$ in their mobile phones. It was important to note their successful installation ensuring that they experienced the intervention media in four weeks. During the intervention period, they decided their own time arrangement to use the game app for vocabulary learning. They were assigned to use Square Talks ${ }^{\circledR}$ for at least four hours per week. They were monitored through the backend database of the game app. At the end of the fourth week, all subjects took a vocabulary post-test. Table 1 shows the results of the pre-test and post-test.

Table 1

The Students' Pre-test and Post-test Scores

\begin{tabular}{cccc}
\hline \multicolumn{4}{c}{ No. Subject Pretest Score Posttest Score } \\
\hline 1 & A & 40 & 50 \\
2 & B & 42 & 62 \\
3 & C & 33 & 50 \\
4 & D & 32 & 61 \\
5 & E & 45 & 63 \\
6 & F & 36 & 49 \\
7 & G & 35 & 59 \\
8 & H & 48 & 63 \\
9 & I & 34 & 51 \\
10 & J & 38 & 59 \\
11 & K & 32 & 52 \\
12 & L & 37 & 60 \\
13 & M & 39 & 55 \\
14 & N & 30 & 49 \\
15 & O & 40 & 53 \\
16 & P & 29 & 51 \\
17 & Q & 27 & 60 \\
18 & R & 42 & 57 \\
19 & S & 40 & 59 \\
20 & T & 37 & 59 \\
21 & U & 36 & 57 \\
22 & V & 33 & 53 \\
23 & W & 43 & 56 \\
24 & X & 40 & 55 \\
25 & Y & 36 & 46 \\
26 & Z & 35 & 50 \\
27 & AA & 39 & 53 \\
28 & BB & 34 & 57 \\
29 & CC & 47 & 62 \\
30 & DD & 28 & 57 \\
31 & EE & 35 & 52 \\
32 & FF & 33 & 48 \\
33 & GG & 27 & 51 \\
34 & HH & 23 & 52 \\
\hline & & & \\
\hline
\end{tabular}


After obtaining the subjects' test scores, the range, the minimum, the maximum, the sum, the mean, the standard deviation, and the variance were calculated. Table 2 shows the result of descriptive statistics.

Table 2

The Result of Descriptive Statistics

\begin{tabular}{cccccccc}
\hline Test & \multicolumn{3}{c}{ Range } & Minimum & Maximum Sum & Mean Standard Deviation & Variance \\
\hline Pretest & 25 & 23 & 46 & 1225 & 36.03 & 5.79 & 33.48 \\
Posttest & 17 & 48 & 63 & 1871 & 55.03 & 4.79 & 22.94 \\
\hline
\end{tabular}

Table 2 shows that the mean of post-test scores (55.03) is higher than the mean of pretest scores (36.03). It indicates that on average, the use of Square Talks® has improved the students' vocabulary test scores by $52.73 \%$. To analyze whether the difference between the post-test and pre-test scores is statistically significant, the paired samples t-test was done. Prior to conducting the paired samples t-test, the assumption of normally distributed test scores and the homogeneity of variance were examined to determine the use of parametric or nonparametric statistical tests. The Shapiro Wilk test was employed to determine the distribution of the data with the level of significance $(\alpha)$ of 0.05 in which the significance value ( $\mathrm{p}$-value) $>0.05$ means that the data are normally distributed. Based on the result of the normality test, the p-value of the pre-test was .980 and the p-value of the post-test was .157 indicating that the data were normally distributed. In addition, the Levene test was employed to determine the homogeneity of variance with the $\alpha=0.05$ in which the $p$-value is greater than 0.05 which means that the data are homogenous. Based on the result of the homogeneity test, the p-value of the mean was .626 and the p-value of the median was .628 indicating that the data were homogeneous. Thus, the paired samples t-test was performed to test the hypothesis and Table 3 depicts the result.

Table 3

The Result of the Paired Samples T-Test

\begin{tabular}{cccccc}
\hline Test & Mean & $\begin{array}{c}\text { Standard } \\
\text { Deviation }\end{array}$ & t-test & df & $\begin{array}{c}\text { t-table } \\
\boldsymbol{\alpha}=\mathbf{0 . 0 5}\end{array}$ \\
\hline Pretest & 36.03 & 5.787 & -19.927 & 30 & \pm 2.042 \\
Posttest & 55.03 & 4.789 & & & \\
\hline
\end{tabular}

It can be seen in table 3 that $t_{\text {obtained }}$ ( $t$-test) is -19.927 . The result of $t_{\text {obtained }}$ and $t_{\text {table }}(t-$ table) is compared by considering the degrees of freedom (df) to test whether the $\mathrm{H}_{\mathrm{o}}$ (null hypothesis) can be rejected. If the result of t-test is higher than t-table at the level of significance $(\alpha)$ of 0.05 as the convention to reject the null hypothesis (Arikunto, 2019), the null hypothesis can be rejected. On the contrary, if the result of t-test is lower than t-table, the null hypothesis cannot be rejected. Referring to Table 3, the $\mathrm{df}$ is 30 in which the t-table with $\alpha=0.05$ is \pm 2.042 . Comparing the value of $t$, the value of $t$-test is higher than the value of $t-$ table $(-2.042<-19.927)$. Thus, there was enough evidence indicating that $\mathrm{H}_{1}$ is accepted and $\mathrm{H}_{\mathrm{o}}$ is rejected.

\section{Subjects' Perceptions and Feedback towards Using Square Talks® as a Vocabulary Learning Tool}

The questionnaire consisted of three sections. The first section was intended to gather information related to the students' duration of playing Square Talks®. The second section consists of questions on user experience focusing on three categories: effectiveness, usability, and satisfaction which revealed the overall acceptance towards using Square Talks® as a 
vocabulary learning tool. The last section of the questionnaire collected data on problems encountered when playing the game app and suggestions for improvement.

Based on the first section of the questionnaire and the backend database of the game app, it was discovered that the average playing time of the students playing Square Talks® per week was more than five times (5.03). There was a variety of duration depending on the playing modes that the students have chosen, between 20 minutes to 1.5 hours per game. All students experienced the three playing modes of the game app: single-player, multiplayer, and versus computer.

According to the second section of the questionnaire, the overall user experience in playing Square Talks ${ }^{\circledR}$ was measured in terms of three dimensions, i.e., effectiveness, usability, and satisfaction by using Likert scale. Each dimension consists of five statements. Table 4 displays the results of the subjects' perceptions towards Square Talks ${ }^{\circledR}$ based on the fifteen statements in the questionnaire.

Table 4

The Students' Perceptions towards Square Talks ${ }^{\circledR}$

\begin{tabular}{|c|c|c|c|}
\hline Dimension & Statement & Mean & $\begin{array}{l}\text { Standard } \\
\text { Deviation }\end{array}$ \\
\hline \multirow{5}{*}{ Effectiveness } & Square Talks $\circledast$ helps me to learn English vocabulary. & 4.74 & 9.74 \\
\hline & $\begin{array}{c}\text { Square Talks } \$ \text { helps me to learn English } \\
\text { pronunciation. }\end{array}$ & 4.12 & 5.74 \\
\hline & Square Talks® helps me to learn English spelling & 4.35 & 6.97 \\
\hline & 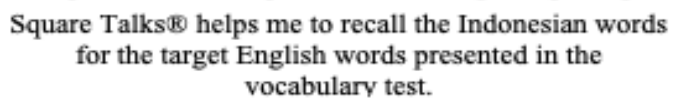 & 4.41 & 7.11 \\
\hline & $\begin{array}{c}\text { Square Talks } \$ \text { helps me to improve English } \\
\text { vocabulary knowledge. }\end{array}$ & 4.82 & 10.85 \\
\hline \multirow{5}{*}{ Usability } & I find it easy to play Square Talks $\mathbb{E}$. & 4.50 & 7.73 \\
\hline & I understand Square Talks $W^{\prime}$ 's game rules. & 4.76 & 10.34 \\
\hline & 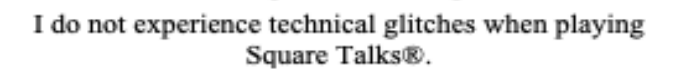 & 4.26 & 6.31 \\
\hline & 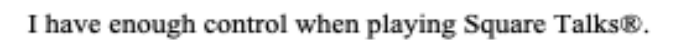 & 4.03 & 5.56 \\
\hline & I feel comfortable when playing Square Talks $\mathbb{B}$. & 4.12 & 5.74 \\
\hline \multirow{5}{*}{ Satisfaction } & I like playing Square Talks $\circledast$ in general. & 4.32 & 6.68 \\
\hline & I understand Square Talks $\mathbb{B}$ 's questions. & 4.09 & 5.78 \\
\hline & I like Square Talks $\circledast$ 's interface. & 4.82 & 10.85 \\
\hline & I like Square Talks ${ }^{\prime}$ 's features and challenges. & 4.68 & 9.45 \\
\hline & 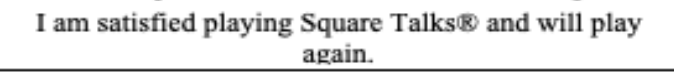 & 4.71 & 9.85 \\
\hline
\end{tabular}

Table 4 shows that the students identified that Square Talks® has enhanced their English vocabulary learning positively, taking into an account that the highest mean for the statement in the effectiveness dimension is "Square Talks ${ }^{\circledR}$ helps me to improve English vocabulary knowledge (4.82). The highest mean for the statement in the usability dimension is "I like Square Talks ${ }^{\circledR}$ in general". Meanwhile, the highest mean in the satisfaction dimension is "I like Square Talks ${ }^{\circledR}$ 's interface" (4.82). The results of the subjects' overall perceptions towards Square Talks ${ }^{\circledR}$ is summarized in table 5.

Table 5

The Students' Overall Perceptions towards Square Talks ${ }^{\circledR}$ Based on Three Dimensions

\begin{tabular}{ccc}
\hline Dimension & Mean Std. & Deviation \\
\hline Effectiveness & 4.49 & 8.80 \\
Usability & 4.34 & 8.28 \\
Satisfaction & 4.52 & 9.33 \\
\hline
\end{tabular}


Table 5 shows that generally, the students showed positive perceptions on the overall three dimensions: the effectiveness of the game app (4.49), the usability of the game app (4.34), and their satisfaction toward the game app (4.52).

In the last section of the questionnaire, several problems encountered by the students and their suggestions to improve Square Talks® were highlighted to provide recommendations for future development of the game app. Table 6 presents problems experienced by the students.

Table 6

Problems Encountered by the Students

\begin{tabular}{ccc}
\hline Problems & Frequency & Percentage \\
\hline No technical glitches & 19 & $55.88 \%$ \\
No repeat question feature & 7 & $20.59 \%$ \\
Need more time to answer the questions & 3 & $8.82 \%$ \\
Voice actors speak too fast & 5 & $14.71 \%$ \\
\hline
\end{tabular}

As it is shown by table $6,55.88 \%$ of the subjects did not experience any technical problems. Related to understanding questions, $44.12 \%$ reported that they experienced difficulties in understanding the questions and thus they needed a repeat question feature (20.59\%), needed more time to answer the questions $(8.82 \%)$, and needed the voice actors to slow down when reading the questions aloud $(14.71 \%)$.

\section{Discussion}

Based on the statistical analysis, there is a significant difference between the means of the vocabulary pre-test and post-test. The analytical result confirms that the subjects' vocabulary learning performance after the experimental treatment was significantly improving that of their performance before the experimental treatment. This present study examines the effectiveness of Square Talks ${ }^{\circledR}$ in increasing EFL beginner learners' vocabulary size. Positively, the result of the statistical analysis shows that the post-test scores were significantly different than the pre-test scores. This finding indicates that the use of mobile game applications like Square Talks ${ }^{\circledR}$ can improve learners' English vocabulary development. The implementation of a mobile game app in this study is evidently effective to make learners experience a more meaningful process of English vocabulary development and successfully increase learners' learning performance. This finding is in line with the studies conducted by Fageeh (2013), Kohnke, Zhang \& Zou (2019), and Yen, Chen, \& Huang (2019) revealing that the use of a mobile game app has influenced the increase of learner's vocabulary test scores.

Based on the first section of the questionnaire, it was discovered that the average playing time of the subjects playing Square Talks® per week was more than five times (5.03) between 20 minutes to 1.5 hours per game. This follows the result of a study conducted by Yen, Chen \& Huang (2019). The subjects in their study played a mobile game app for English vocabulary learning on an average of five hours per week and the analytical results confirmed superior after treatment test scores with the improvement of their performance by $51.95 \%$. This distinctly suggests that the duration of the subjects using the game app for English vocabulary learning plays a factor in a more successful learning experience.

The second section of the questionnaire revealed that generally, the students showed positive perceptions on the overall three dimensions. These positive results follow the previous studies (Gamblo, 2019; Li, 2021; Wu, 2018; Yen, Chen \& Huang, 2019). They concluded that after the implementation of EFL vocabulary mobile-based game learning, 
learners manifested positive attitudes toward the use of the game app in enhancing their vocabulary learning development. Similarly, the subjects in this study showed a positive attitude toward English vocabulary learning using Square Talks®.

In the third section of the questionnaire, the majority of the students did not experience any technical issues. However, the remaining $44.12 \%$ might experience technical glitches but did not report them, probably because they were minor problems that did not interfere with the playing process. Furthermore, some students experienced difficulties in understanding the questions and thus they needed a repeat question feature, needed more time to answer the questions, and needed the voice actors to slow down when reading the questions aloud. A possible explanation for this issue is that despite the differences in their pre-test and post-test scores, some students might have difficulties in comprehending the spoken instructions and questions due to the possibly low English listening comprehension skills. As Zou \& Li (2015) highlighted that user-friendly mobile game apps made students feel enthusiastic and show eagerness in learning, it is advisable that the game app developers revisit the questions to provide a feature to assist learners with low English listening ability.

\section{CONCLUSION}

This study examined learners' vocabulary development and perceptions while using Square Talks® as a vocabulary learning tool. First, the study showed that Square Talks ${ }^{\circledR}$ has enabled learners to improve their English vocabulary learning performance. Second, the survey indicated that learners exhibited positive perceptions toward Square Talks®. Therefore, Square Talks® can be considered to be an alternative learning tool to facilitate EFL beginner learners' vocabulary development.

However, due to the small number of subjects in this study, it should be noted that the findings cannot be generalized to the larger population. Hence, it is suggested that further empirical studies to evaluate and explore the effectiveness of Square Talks® should be conducted by expanding the sample size and adding a delayed vocabulary post-test to provide a more in-depth insight on the use of mobile game applications to enhance English vocabulary development.

\section{ACKNOWLEDGEMENT}

The authors would like to thank the Directorate of Research and Community of Telkom University for financial support in developing Square Talks ${ }^{\circledR}$.

\section{REFERENCES}

Akhriana, S. A. A. (2019). Perancangan Aplikasi Pembelajaran Bahasa Inggris Berbasis Android. Jurnal Sistem Informasi dan Teknologi Informasi, 8(2), 100-110. DOI: https://doi.org/10.36774/jusiti.v8i2.611

Arikunto, S. (2019). Prosedur Penelitian. Jakarta: Rineka Cipta.

Basal, A., Yilmaz, S. Tanriverdi, A., \& Yildiz, L. S. (2016). Effectiveness of Mobile Applications in Vocabulary Teaching. Contemporary Educational Technology, 7(1), 47-59.

Cahyono, B. Y., \& Widiati, U. (2008). The Teaching of EFL Vocabulary in the Indonesian Context: The State of the Art. TEFLIN Journal, 19(1), DOI: http://dx.doi.org/10.15639/teflinjournal.v19i1/1-17

Cameron, L. (2001). Teaching Languages to Young Learners. New York: Cambridge University Press.

Carcamo, M. M. A., Cartes, R. A. C, Velàsques, N. E. E., \& Larenas, C. H. D. (2016). The Impact of Multimodal Instruction on the Acquisition of Vocabulary. Trabalhos em 
Linguística

Aplicada,

$55(1)$

$129-154$

DOI: https://doi.org/10.1590/010318134842170942

Chukharev-Hudilainen, E., \& Klepikova, T. A. (2016). The Effectiveness of Computer-Based Spaced Repetition in Foreign Language Vocabulary Instruction: A Double-Blind Study. CALICO Journal, 33(3), 334-354. DOI: https://doi.org/10.1558/cj.v33i3.26055

Chun, D. M., \& Plass, J. L. (1996). Effects of Multimedia Annotations on Vocabulary Acquisition. Modern Language Journal, 80(2), 183-198. DOI: https://doi.org/10.1111/j.1540-4781.1996.tb01159.x

Deris, F., \& Shukor, N. (2019). Vocabulary Learning through Mobile Apps: A Phenomenological Inquiry of Student Acceptance and Desired Apps Features. International Association of Online Learning Engineering, 13(7), 129-140. DOI: http://doi.org/10.3991/ijim.v13i07.10845

Fageeh, A. A. I. (2013). Effects of MALL Applications on Vocabulary Acquisition and Motivation. Arab World English Journal, 4(4), 2013. Retrieved on September 17, 420447.

Gamlo, N. (2019). The Impact of Mobile Game-Based Language Learning Apps on EFL Learners' Motivation. English Language Teaching, 12(4), 49-56. DOI: https://doi.org/10.5539/elt.v12n4p49

Goz, F., \& Ozcan, M. (2017). An Entertaining Mobile Vocabulary Learning Application. The Eurasia Proceedings of Educational \& Social Sciences (EPESS), 7(1), 63-66.

Harmer, J. (2002). The Practice of English Language Teaching: Third Edition. Malaysia: Longman.

Klimova, B., \& Polakova, P. (2020). Students' Perceptions of an EFL Vocabulary Learning Mobile Application. Educational Sciences, 10(37), 1-8. DOI: http://doi.org/10.3390/educsci10020037

Kohnke, L., Zhang, R., \& Zou, D. (2019). Using Mobile Vocabulary Learning Apps as Aids to Knowledge Retention: Business Vocabulary Acquisition. The Journal of Asia TEFL, 16(2), 683-690. DOI: http://doi.org/10.18823/asiatef1.2019.16.2.16.683

Kukulska-Hulme, A., \& Traxler, J. (Eds.). (2005). Mobile Learning: A Handbook for Educators and Trainers. Open and Flexible Learning Series. London: Routledge.

Li, R. (2021). Does Game-Based Vocabulary Learning App Influence Chinese EFL Learners' Vocabulary Achievement, Motivation, and Self-Confidence? Sage Open Journal, 11(1), 1-12. DOI: https://doi.org/10.1177/21582440211003092

Li, R., Meng, Z., Tian, M., Zhang, Z., \& Xiao, W. (2019). Modelling Chinese EFL Learners' Flow Experiences in Digital Game-Based Vocabulary Learning: The Roles of Learner and Contextual Factors. Computer Assisted Language Learning, 34(4), 483-505. DOI: https://doi.org/10.1080/09588221.2019.1619585

Liu, P. (2016). Mobile English Vocabulary Learning Based on Concept-Mapping Strategy. Language Learning \& Technology, 20(3), 128-141. DOI: http://doi.org/10125/44485

Lotfolahi, A. R., \& Salehi, H. (2017). Spacing Effects in Vocabulary Learning: Young EFL Learners in Focus. Cogent Education, 4(1), 1-10. DOI: http://doi.org/10.1080/2331186X.2017.1287391

Ludwig, C. (2018). Using Vocabulary Apps to Enhance Students' Vocabulary Knowledge. Studies in Self-Access Learning Journal, 9(3), 306-323. DOI: https://doi.org/10.37237/090305

Mayer, R. E., \& Moreno, R. (2003). Nine Ways to Reduce Cognitive Load in Multimedia Learning. Educational Psychologist, 38(1), 43-52. DOI: http://doi.org/10.1207/S15326985EP3801_6 
Naderi, B. (2017). Effect of Spaced Repetition on Iranian EFL Learners' Form Recall of English Single Words and Collocations. International Journal of Foreign Language Teaching \& Research, 5(19), 51-60.

Nation, I. S. P. (2008). Teaching Vocabulary: Strategies and Techniques. Boston: Heinle Cengage Learning.

Nation, I. S. P., \& Beglar, D. (2007). A Vocabulary Size Test. The Language Teacher, 31(7), 9-13.

Pareja-Lora, A., Arús-Hita, J., Read, T., Rodríguez-Arancón, P., Calle-Martínez, C., Pomposo, L., Martín-Monje, E., \& Bárcena, E. (2013). Toward Mobile Assisted Language Learning Apps for Professionals that Integrate Learning into the Daily Routine. In L. Bradley \& S. Thouësny (Eds.), 20 Years of EUROCALL: Learning from the Past, Looking to the Future: Proceedings of the 2013 EUROCALL Conference, 206210. DOI: http://doi.org/10.14705/rpnet.2013.000162

Pavlik, J. V. (2005). Fueling a Third Paradigm of Education: The Pedagogical Implications of Digital, Social, and Mobile Media. Contemporary Educational Technology, 6(2), 113125.

Rezaei, A., Neo, M., \& Pesaranghader, A. (2013). Effectiveness of Using English Vocabulary Mobile Applications on ESL's Learning Performance. Proceedings of 2013 International Conference on Informatics and Creative Multimedia, 1-21. DOI: http://doi.org/10.1109/ICICM.2013.27

Richards, J. C., \& Schmidt, R. (Eds.). (2002). Longman Dictionary of Language Teaching and Applied Linguistics: Third Edition. New York: Longman.

Rohmatillah (2017). A Study on Students' Difficulties in Learning Vocabularies. Jurnal Tardis Bahasa Inggris, 6(1), 69-86. DOI: https://doi.org/10.24042/ee-jtbi.v6i1.520

Salam, U., \& Nurnisa. (2021). Students' Difficulties in Learning Vocabularies. English Community Journal, 5(1), 46-53. DOI: https://doi.org/10.32502/ecj.v5i1.3327

Schmitt, N. (2008). Review Article: Instructed Second Language Vocabulary Learning. Language Teaching Research, 12(3), 329-363. DOI: https://doi.org/10.1177/1362168808089921

Schrepp, M., Hinderks, A., \& Thomaschewski, J. (2014). Applying the User Experience Questionnaire (UEQ) in Different Evaluation Scenarios. In A. Marcus (Ed.): Design, User Experience, and Usability. Theories, Methods, and Tools for Designing the User Experience. Lecture Notes in Computer Science, 8517, 383-392. DOI: https://doi.org/10.1007/978-3-319-07668-3_37

Stockwell, G., \& Hubbard, P. (2013). Some Emerging Principles for Mobile-Assisted Language Learning. International Research Foundation for English-Language Education. Retrieved on August 18, 2020 from https://www.tirfonline.org/wpcontent/uploads/2013/11/TIRF_MALL_Papers_StockwellHubbard.pdf

Toroghi, E. E., \& Anaraki, S.S. (2015). The Effect of Multimodal Instruction on EFL Learners' Vocabulary Learning. Proceedings of the First Conference in Challenges in Foreign Language Teaching in Iran.

Wozniak, P. A., \& Gorzelanczyk, E. J. (1994). Optimization of Repetition Spacing in the Practice of Learning. Acta Neurobiologiae Experimentalis, 54(1), 59-62.

$\mathrm{Wu}, \mathrm{T}$. (2018). Improving the Effectiveness of English Vocabulary Review by Integrating ARCS with Mobile Game-Based Learning. Journal of Computer Assisted Learning, 34(3), 315-323. DOI: https://doi.org/10.1111/jcal.12244

Yen, L., Chen, C., \& Huang, H. (2019). Effects of a Mobile Game-Based English Vocabulary Learning App on Learners' Perceptions and Learning Performance: A Case Study of Taiwanese EFL Learners. ReCALL, 31(2), 170-188. DOI: https://doi.org/10.1017/S0958344018000228 
Yip, F.W., \& Kwan, A.C. (2006). Online Vocabulary Games as a Tool for Teaching and Learning English Vocabulary. Educational Media International, 43(3), 233-249. DOI: https://doi.org/10.1080/09523980600641445

Zarei, G. R., \& Khazaie, S. (2011). L2 Vocabulary Learning through Multimodal Representations. Procedia-Social and Behavioral Sciences, 15, 369-375. DOI: https://doi.org/10.1016/j.sbspro.2011.03.104

Zou, B., \& Li, J. (2015). Exploring Mobile Apps for English Language Teaching and Learning. In F. Helm, F., Bradley, L., Guarda, M. \& Thouësny, S. (Eds.). Critical CALL-Proceedings of the 2015 EUROCALL Conference, 564-568. DOI: https://dx.doi.org/10.14705/rpnet.2015.000394 